\title{
Life cycle of a moat: a detailed micromorphological examination and broader geoarchaeological survey at the late Neolithic Wadian site, Central China
}

\author{
Yijie Zhuang ${ }^{1}$, Hai Zhang ${ }^{2}$, Yanming Fang ${ }^{3}$, Hui Wang ${ }^{4}$ \\ 1 Institute of Archaeology, University College London, 31-34 Gordon Square, London, \\ WC1H OPY, UK, y.zhuang@ucl.ac.uk, tel.: 0044(0)2076791539 \\ 2 School of Archaeology and Museology, Peking University, 5 Yiheyuan Road, Beijing, \\ 100871, China, haizhang@pku.edu.cn \\ 3 Henan Provincial Institute of Cultural Relics and Archaeology, 9 Longhai North \\ Three Street, Zhengzhou, 450000, China, 1104276344@qq.com \\ 4 Institute of Archaeology, Chinese Academy of Social Sciences, 27 Wangfujing Street, \\ Beijing, 100710, China, wh@cass.org.cn
}

Corresponding authors: Yijie Zhuang (y.zhuang@ucl.ac.uk) and Hui Wang (wh@cass.org.cn)

\begin{abstract}
Moats and rammed earth walls are two key criteria considered by many archaeologists as the universal characteristics of late Neolithic 'cities' in China. However, archaeological evidence of their construction and maintenance remains ambiguous. We investigate the taphonomical and functional issues of the moat excavated at Wadian in Central China by conducting a detailed micromorphological examination of soil samples. The construction of this moat coincided with high groundwater table and the initial stage of its use benefited from this favorable hydrological condition while it was still connected with natural water bodies. However, the moat gradually silted up due to increased cultural activities, changing sedimentary processes, and fluctuating hydrological conditions at the site. The frequent alternations between wet and dry conditions dominated the last stage of the life cycle of the moat and it probably lost its original functions at this stage before it was completely silted up. Such changing sedimentary regime and fluctuating hydrology were confirmed by our geoarchaeological survey in the region. Our research provides crucial information concerning the construction, maintenance and abandonment of this moat and how these processes were related to subsistence strategies and local environmental changes.
\end{abstract}

\section{Highlights}

- For the first time micromorphology and geoarchaeological surveys were conducted to examine the construction and maintenance of a late Neolithic moat in China

- The moat was connected with natural water bodies at the beginning of its construction and was gradually silted up over time

- This study provides environmental evidence for the cultivation of rice in late Holocene North China

\section{Keywords}

Moat, taphonomy, micromorphology, geoarchaeology, late Neolithic China 


\section{Introduction}

Moats, or causewayed enclosures, were a prevailing monumental feature in prehistoric Europe and China. Moats fundamentally separate human settlements from their natural environments and their construction marks a profound development in human history in terms of territoriality and cultural landscapes (Albrecht, 2014; Whittle et al, 2011). Many studies in the UK and across Europe have demonstrated that, moats, once constructed, became the central venue and focal point for economic and cultural activities in prehistoric settlements (e.g., Valera, 2014). Such research, in turn, has prompted the development of excavation methods for finding detailed information regarding the construction, maintenance and abandonment of moats, in which geoarchaeology has played a leading role (e.g., Bishop et al., 2003; Boyd et al., 1999). The earliest known moats or ditches in China were dug at Xinglongwa in what is now the Western Liao River (Shelach and Teng, 2013) and at Bashidang in the Middle Yangtze River (Pei, 2004), both dated to around $8000-7000 \mathrm{cal}$. BP. Represented by the settlement plan unearthed at the site of Jiangzhai, where several groups of houses formed a circle and were surrounded by a moat, moats became a prominent characteristic of the Yangshao period settlements (ca.7000-5000 cal. BP) (Institute of Archaeology, 1963). By the late Neolithic period (ca. 5000-4000 cal. BP), much larger moats were being built. They encircled rammed-earth walls which was a new development in the settlement structure of the time (Liu and Chen, 2012). This new phenomenon of larger moats would suggest greater labour investment. These large moats formed part of new cultural landscapes, one that was characterised by expanding territories, increasing spatial divisions within the settlements and social stratification; trends which had already begun during the late Yangshao period as seen at the site of Xi'shan (Henan Provincial Institute of Cultural Relics and Archaeology and Xinmi Historical Association of Yan-Huang, 2002).

Whilst much scholarly efforts have been dedicated to researching the functions and significance of the late Neolithic moats and rammed-earth walls in China, other related issues have been left largely unexplored. For instance, very little is known regarding the taphonomy of the moats. How did the construction and use of the moats and walls fundamentally transform local and regional landscapes? How should this new type of cultural landscape be viewed within its wider ecological and environmental context? And are there functional differences amongst the moats discovered in different parts of China and if so, why? Through a detailed micromorphological examination of soil samples collected during the excavation of the moat at the Wadian site in central China and a geoarchaeological survey in the surrounding area, this article addresses the taphonomical and functional issues raised above. More specifically, this research provides crucial information concerning the life cycle, or in other words, the construction, maintenance and abandonment of the moat and how these processes were related to local environmental changes. This research will help to contextualize the subsistence strategies and domestic activities at the site and in the surrounding environment as informed by the archaeobotanical research. 


\section{Environmental and archaeological backgrounds}

The late Holocene geomorphological process in the middle Ying River basin in the Henan Province (Figure 1), where the Wadian site is located, is dominated by continuous eolian and colluvial activities, whereas in the lower catchment of the river, it is dominated by active alluvial and colluvial activities. Particles of the windblown materials deposited in the upper Ying River are, according to some research, coarser than those in the western region, which are closer to the source of typical wind-blown loess (Li, et al., 2008). The presence of these coarser particles suggests that some of the loessic sediments in the Ying River basin are of local origin. One important source is the reworked loess that is transported by river water and redeposited on the bare surface of nearby floodplains. In addition to the deposition of reworked loess was colluviation, directly resulting from human activities such as stone quarry and lithic production (cf. Pang et al., 2013). Compared to the upper and middle reaches, the alluvial activities were more active in the lower Ying River and combined with colluviation resulted in a higher sedimentation rate. However, the river channel remained stable before ca. 2000 BP (Warring States to Qin/Han periods), during which time palaeosols were formed. From $2000 \mathrm{BP}$ onwards the river began a significant downcutting process (Xu et al., 2013), followed by frequent changes of its channels in the lower catchment. This increase in channel avulsion was caused by a number of factors. Apart from changes in regional tectonic structure and erosion basal line, fundamental shifts in river hydrology, caused by increased erosion due to intensified land use and climate change, would have also been crucial factors. As revealed by a study on charcoal recovered at Wadian, climate during the occupation of the site was humid and warm. The landscape was dominated by typical subtropical-temperate vegetation of evergreen, deciduous trees such as Quercus sp., Zelkova sp., Ulmus sp., and Cyclobalanopsis sp., with the presence of typical sub-tropical species such as bamboo. These tree resources were utilized not only for food (e.g., acorn consumption) but also for fuel, construction and other purposes (Wang et al., 2012).

The archaeological evidence of settlement density suggests that vast areas of Central China were densely populated during the late Neolithic. Many of the settlements were located along tributaries of major rivers such as the Yellow and Huai River. As a tributary of the Huai River, the Ying River was also occupied by many late Neolithic settlements. Twenty-four Longshan period sites have been found in the upper and middle Ying River (School of Archaeology and Museology and Henan Provincial Institute of Cultural Relics and Archaeology, 2007). The lower catchment was sporadically occupied by fewer sites, but it is also likely that many more sites were covered by the elevated sedimentation process from the Bronze Age onwards. The Wadian site is situated on the second terrace at the confluence of the middle Ying River and the Huaji River. The Ying River turns dramatically from a north-south to a west-east direction near the site (Figure 2). Therefore, the water velocity here is significantly reduced and the sedimentation rate therefore correspondingly increased. This process encouraged bank erosion on one side but on the opposite side of the river, a large-sized river floodplain was formed. The latter, on top of which many modern villages are now located, must have been an ideal place for late-Neolithic settlement construction and related economic activities to take place 
at Wadian. The overall plan of the site is still largely unknown. Nonetheless, it is now clear that, after a systematic coring survey, the site is more than one million $\mathrm{m}^{2}$ in size, surrounded by a moat of roughly rectangular shape. Parts of the encircled area were excavated during the 1980-1982, 1997 and 2007-2008 excavation seasons resulting in many houses, numerous pits, ditches and burials being unearthed (Henan Provincial Institute of Cultural Relics and Archaeology, 2004). The discoveries of sacrificial pits within the houses, in which animal and human bones were found, along with other artefacts such as jade, elaborate ceramics with polished surfaces, and divination bones would indicate the regional importance of this site (Henan Provincial Institute of Cultural Relics and Archaeology, 2004). Indeed, some scholars regard it as a regional center and have drawn parallels with other regional centers such as Wangchenggang and Xinzhai in the nearby river basins (Zhao, 2013).

Archaeobotanical, zooarchaeological and bioarchaeological research has provided information regarding past land use and subsistence at the site. In the flotation samples collected from different archaeological contexts at Wadian, carbonized seeds included foxtail millet (Setaria italic), broomcorn millet (Panicum miliaceum), rice (Oryza sativa), soybean (Glycine max) and many weed seeds, as well as seeds of wild vegetables such as beefsteak plant (Perilla frutescens) and fruits such as grape (Vitis), Chinese jujube (Ziziphus), and peach (Prunus persica) (Liu and Fang, 2010). Seeds of the cultivated crops account for a high proportion of the total archaeobotanical assemblage. The presence of weed seeds would suggest that these crops were being cultivated locally. Amongst the cultivars, the presence of rice is significant and provides additional supporting evidence along with other archaeobotanical studies from the region that the late Holocene saw an increase in rice farming (Fuller and Zhang, 2007; Jin et al., 2007; Song, 2011). The abundance of both carbonized seeds and charcoal is much lower in the flotation samples collected from the moat than in other contexts. However, the abundance of charcoal is higher in the samples collected from the bottom of the moat than in the upper part of the moat. This pattern is analogous to that found in similar contexts at the site of Wangchenggang (Zhao and Fang, 2007). Based on this evidence, some researchers think that the moats at both sites were actively used most of the time for draining during the flooding seasons and defense and remained filled with water even after the sites were abandoned. It was this constant water flow which resulted in the lensliked sedimentation pattern found in the charcoal (cf. Zhao and Fang, 2007). This pattern was cross-checked in our geoarchaeological investigation and the results are discussed below.

Thirty-two taxa have been identified from the faunal assemblage unearthed from the 1997 excavation season. Domestic mammals include pigs, dogs, cattle and sheep (Lu, 2009). While domestic pigs, particularly the sub-adults or juveniles, and sheep scapula were used for sacrificial ceremonies and divination, cattle were consumed for their meat and bone marrow. Cattle bones were the main source for the production of bone tools (Lu, 2009). Strontium isotopic analyses of pig, sheep and cattle bones indicate that the sheep, cattle and some of the pigs were not born locally, whereas other pigs were of local origins. Although the sample size of this research is still small $(n=7)$ (Zhao et al., 2012), it does provide insight into the animal 
husbandry strategies adopted at the site, which are another important aspect that will be discussed within the scope of our micromorphological analysis.

\section{Materials and methods}

Only the western side the rectangular shaped moat at Wadian has survived postdepositional disturbance. It is around $890 \mathrm{~m}$ long, measuring between $18-20 \mathrm{~m}$ in width according to the coring survey. Part of this section was excavated in 2007. It shows a pan-liked shape, ca. $5 \mathrm{~m}$ in depth, ca. $9.5 \mathrm{~m}$ in width at the bottom and $20 \mathrm{~m}$ in width at the top (Figure 3). Three sets of soil blocks (44 in total) were collected during the excavation (Figures $3 \mathrm{~b}$ ). Twelve of the blocks (each is divided into two sub-blocks) were processed and analyzed at the McBurney Laboratory for Geoarchaeology at University of Cambridge following the method described by Murphy (1986), with modifications by Julie Boreham, Charles French and Tonko Rajkovaca. These thin sections were examined using a polarizing microscope in plane-polarized and cross-polarized lights following the guidelines developed by Bullock et al. (1985) and Stoops (2003).

A regional geomorphological and geoarchaeological survey was carried out in 2014 to understand alluvial activities that shaped the middle to late Holocene river geomorphology and how these activities were related to the occupation at the site. During the geoarchaeological survey, many Holocene sedimentary sequences and OSL dating samples were collected. The preliminary results of this survey have been published (Wang et al., 2015). The implications of the survey results in relation to the micromorphological examination will be discussed further below. Charcoal and faunal material was collected from several layers in the moat for radiocarbon dating during the excavation. The dating results fall in the time range between 4140 and 3530 cal. BP (Table 1), which are younger than what the accepted pottery typology would suggest (c. 4500-4000 BP). Possible reasons for this chronological discrepancy will be discussed elsewhere.

\section{Results of the geomorphological survey}

The evolution of the Holocene landscape in the Ying River Basin is characterised by the active alluvial cycles between river down-cutting and terrace aggradation. After continuous aggradation of the riverbed due to the increased supply of wind-blown loess in the late Pleistocene, the river began the down-cutting process during the transition from the Pleistocene to the Holocene. River channel avulsion and migration ceased and the river terrace developed on the previous alluvial plain (Figure 4a). By the middle Holocene, the down-cutting process gave way to the aggradation of the river channel and terrace. The height between the riverbed and the terrace was shortened (Figure 4b). River down-cutting was resumed from around 2000 BP onwards with a greater magnitude. In some places, rivers were cut down by 10 metres (Figure 4c). This meant that the riverine landscape remained stable without being punctuated by evident aggradation until the later historical period (ca. 8-9 $9^{\text {th }}$ Century AD?) when another short period of sedimentary alternations between cultural horizons rich in anthropogenic inclusions and colluvial deposits took place (Figure 4d). It would appear that the landscape cycles between stability and instability have accelerated since the late historical period, partly driven by the 
intensified human engineered landscape that fundamentally altered the processes of landscape evolution.

Our geoarchaeological survey revealed a relatively high groundwater table at Wadian during the middle to early late Holocene when precipitation was ample. This has been further supported by the following evidence: First, as previously discussed above, the river valley had been aggrading since the middle Holocene, resulting in increasingly shallower depths between the terrace and the riverbed. Second, lacustrine deposits are commonly found on the terrace (Figure 4), indicative of the existence of lakes during the middle to early late Holocene. Third, the high groundwater level found during the survey is in accordance with the results of the micromorphological examination.

\section{Results of the micromorphological examination}

Five major stages regarding the construction, use, gradual silting up and eventual abandonment of the moat were observed in the examination of the thin sections. Detailed information on the microstructure, groundmass, inclusions and pedofeatures is provided in Table S1. Below is a summary of the main micromorphological features and our interpretations.

The moat was built on top of some archaeological features as evidenced by the presence of postholes underneath (Figure 3). The sediments cut by these postholes are dominated by fine laminae consisting of rounded-shaped minerals of very fine sand and fine sand sizes, typical of the alluvial deposits in this region (Li et al., 2008). This suggests that the archaeological features and the moat were built on top of an alluvial plain that was possibly seasonally inundated and replenished with alluvial deposits.

Stage 1 (Figure 9a): The palaeo-surface when the moat was initially dug was likely lower than that found at the excavation as the bank would have also aggraded through time. This is important as it means that the moat at the beginning of its inception coincided with a relatively higher groundwater level, or indeed, it was a time when the moat was connected with the river or natural water bodies nearby. This is supported by the following evidence: first, the groundmass of the corresponding thin sections (see Table S1 for thin section numbers, same below) is predominantly well-sorted, fine-sand-sized quartz and other minerals (Figure $5 \mathrm{~b}$ and e), suggestive of a sedimentary regime that is largely controlled by water flow of relatively high energy to allow proper sorting of sediments, similar to that before the construction of the moat. Second, the presence of iron and manganese nodules implies that there was a period of post-depositional water saturation (Lindbo et al., 2010, McCarthy and Plint, 1998, McCarthy and Plint, 1999), although it is difficult to know when exactly these iron nodules were formed. Third, there is a scarcity of typical clayey material that would be deposited in standing water. Surface runoff also washed abundant eroded soil aggregates, ceramic sherds, bone fragments and charcoal (Figure 5a-e), as well as dung fragments into the moat during this stage. These anthropogenic inclusions were relatively poorly sorted, with random orientations suggestive of their local origin and pointing to poor vegetative surface 
coverage prone to erosion. In contrast, the abundance of anthropogenic inclusions was significantly reduced at the end of this stage, probably due to improved surface conditions.

Stage 2 (Figure 9b): The maintenance of the moat at this stage involved digging and cleaning. In some thin sections, evidence of digging activities was preserved. Two symmetric grooves, for instance, were found in sample A1-down (Table S1), which could have been tool marks left by sharp tools digging into sediments that were rich in eroded materials (Figure 10). These grooves were then filled with relatively 'clean' sediments with fine laminae that were deposited when the velocity and energy of the water were high and when there was not much surface erosion taking place. It is unclear whether it was deliberate maintenance that caused the change in sedimentation regime or the result of a hydrological fluctuation in the local region.

Stage 3 (Figure 9c): The moat was in continuous use, but with steady deposition of alluvial-like sediments, characterised again by well-sorted, fine to very fine sandsized minerals. Evidence of cleaning is absent. This would mean that the deposition was continuous without disruption caused by desilting. It is unclear whether this was due to less care being spent in the maintenance of the moat or a significant change in the sedimentation regime. More information is needed to answer this question. With the gradual but steady aggradation of sediments from the bottom, the moat became even shallower. This would have fundamentally impacted upon the use of the moat. Indeed, periods of low water levels occurred, causing the formation of clay textual features (Figure 5g-h, Figure 6a-d and g-h) along channel voids where hydrophilic plants were growing. Some of these textual features are characterised by their coarse particles (silty clay) and blackish, dark color, indicative of very poor sorting (Figure 5g-h, Figure $6 \mathrm{c}$ and g). During these low water level events, the sediments were still submerged under the water, however, both the redoximorphic and illuviation activities were taking place along the channels as the roots of plants were experiencing frequent wet-dry (aerobic and anaerobic) alternations (Bridge, 2003; Lindbo et al., 2010; McCarthy et al., 1998). Some clay textual features have a typical layered (Figure 6h) or compound structure, juxtaposing with calcitic features (Figure $6 \mathrm{a}$ and $\mathrm{b}$ ). These further confirm the periodic dry conditions. However, these low water level episodes did not last long as the pedofeatures were dominated by iron and manganese nodules and associated with iron depletion areas, typical features formed in water saturation conditions (Kovda and Mermut, 2010). The deposits are relatively 'clean', with a significant reduction of anthropogenic inclusions (Figure 6e-f), compared to the underlying horizons. This might be related to improved surface vegetation cover that reduced surface erosion and/or more careful management of the nearby land.

Stage 4 (Figure 9d): The gradual silting up of the moat at this stage was evidenced by the continuous sedimentary aggradation from the bottom of the moat. The hydrology changed dramatically as the water became shallower, causing frequent wet-dry alternations. The periodic dry conditions encouraged the formation of different kinds of pedofeatures in the alluvial-like materials. Thus, instead of being dominated by the upward sedimentary aggradation as seen during the early stages 
(described above), this period witnessed both continuous upward aggradation of the sediments and active downward pedogenetic processes. The latter are characterised by the formation of abundant layered dusty clay textural features (Figure 7b-d), insitu or disrupted surface crustal features (Figure $8 \mathrm{~h}$ ) and occasionally calcitic nodules (Figure 7a). These pedogenetic processes were taking place along with surface disturbance that resulted in the increased abundance of dispersed particles, including micro-charcoal and fine particles, ready to be translocated and reprecipitated with capillary water as silty clay coatings (Figure 7g) (cf. Fedoroff et al., 2010; Kemp et al., 2001; Kuhn et al., 2010; Pagliai and Stoops, 2010). When the situation was wetter, manganese features were formed (Figure 7e). Charcoal, bone and dung fragments (Figure $7 \mathrm{~h}$ ), and other anthropogenic inclusions are occasionally present, but the groundmass of the deposits remains 'clean' overall. This indicates that, while there was possibly the lack of regular cleaning of the moat, no intensive economic activities were taking place on the nearby land, which might have been a deliberate management strategy.

Stage 5 (Figure 9e): At the end of this stage, the moat was almost completely filled up, with the bottom now being close to the surface. While the sedimentary and pedogenetic processes similar to those described above continued, the hydrological condition became more precarious. This hydrological volatility was partly caused by the further reduction in the depth of the moat, but was related to wider hydrological and environmental changes in the region as well (see session 5.2). In some slides, the condition becomes very muddy, and dark silty clay coatings were formed. These coatings are often located along the lower halves of voids with layered structures (Figure 8b-d and g) (cf. Gerrard, 1992; McCarthy and Plint, 1998, 1999). The absence of a strong birefringence under XPL suggests that they were formed when the soil was quickly saturated which did not last long, leaving not time for sorting. Of particular interest is the formation of abundant so-called 'silty clay concentration features' (SCCF) (Figure 8e-f). These features, with stipple speckled b-fabrics, are mainly composed of silt sized particles. Lee, French, \& Macphail (2014) carefully define different types of SCCFs and their formation conditions. They suggest that SCCFs are diagnostic features formed under repeated redoximorphic conditions in disturbed soils such as seasonally flooded and dried paddy fields. In the Wadian case, the combination of the silting up of the moat and the dramatic hydrological change creates a similar condition for the formation of SCCFs, with the silt-sized, readily dispersed particles coming from the highly disturbed surface. Associated with these are the whitish, iron-depleted areas in the groundmass of the thin sections examined, being formed as a result of strong chemical alteration under submerging condition and intensive hydrolysis (cf. Vepraskas, 2001). In other slides, however, the pedogenetic process was dominated by the formation of dusty or limpid clay textural features (Figure $7 f$ and $8 g$ ), typical products in seasonally alternating wet-dry conditions. Following this was the recommence of another period of entire submergence. Such a high frequency of dramatic hydrological changes leads to a hypothesis that needs to be tested in the future, that is, could this be due to artificial control of the water level of the moat when it was re-dug and reused? Abundant anthropogenic inclusions were preserved (Figure 8a-b), which is associated with intensified cultural activities in the vicinity. 
The last stage of the use of the moat was marked by the complete filling up of it. Even though minor hydrological fluctuations may have continued in the soil as evidenced by its different sediment texture from that of outside the moat, the active sedimentary and pedogenetic processes had ceased.

\section{Discussion: Moats and late prehistoric landscapes in North China Construction of the Moat at Wadian and its implications}

Moats and earthen (sometimes stoned) walls are considered two key components for classifying/identifying prehistoric 'cities' by Chinese archaeologists (Zhao and Wei, 2002). Construction of moats and walls became a widespread endeavor across North and Central China during the late Neolithic, with huge resources being dedicated to their construction. The choice of suitable landform locations was vitally important to the construction of these moats. Our geomorphological survey at Wadian and its surrounding area has found that the second river terrace where the site is located received continuous alluvial sediments from the middle Holocene onwards (Figure 10), resulting in the sedimentation of thick alluvial deposits and the formation of large-sized flat lands, which are ideal for the construction of the large-sized moat and settlement. In addition, this type of construction could not have been achieved without developing earth-pounding technologies. Although wall construction had already begun in the late Yangshao period at the aforementioned Xishan site, new technologies for building large-scale earthen works were invented by the late Neolithic Longshan period. As can be clearly seen on the Guchengzhai wall, wooden and bamboo stakes and plates were placed inside the earthen walls to strengthen the high walls. In addition, the concentrated holes between the rammed-earth layers suggest that heavy sticks were used to pound the earth (Henan Provincial Institute of Cultural Relics and Archaeology and Xinmi Historical Association of Yan-Huang, 2002). The tools used for digging the earth may still have been stone spades and other simple tools. However, the organisation for the production of stone tools changed dramatically at this time. A recent survey in the Ying River provides important evidence of systematic quarrying of stone resources, including organised production of stone tools and potentially long-distance trade at Wadian and surrounding regions from the end of the Neolithic onwards. One of the main products from this organised lithic industry were stone spades for earth working (Pang et al., 2013). As previously mentioned the presence of tool marks preserved in the thin sections examined at Wadian indicates the use of tools in cleaning and maintenance. It is thus reasonable to suggest that similar tools, probably those with sharps edges, were used in construction. Third and most important was the enormous labor investment and economic input required not only for the initial construction but the regular maintenance of the moats and walls. For example, the volume of earth removed to build the walls at the Shijiahe walled site in the Middle Yangtze River, according to a recent study, has been estimated to have been $500,000 \mathrm{~m}^{3}$, which would have required 1000 laborers working for 10 years, who would have had to be fed by 20,000-40,000 people (Nakamura, 1997, in Zhang, 2013, pp. 519). A similar estimation for the construction of the Wangchenggang walled site, not far from Wadian, suggests that it would have needed at least 14 months of work by 1000 adult laborers (working 8 hours per day) (School of Archaeology and Museology and 
Henan Provincial Institute of Cultural Relics and Archaeology, 2007). Around $22,400 \mathrm{~m}^{3}$ of earth would have been removed to dig the surviving $890 \mathrm{~m}$ long moat at Wadian, giving the average depth was ca. $3 \mathrm{~m}$ (see above). Assuming one worker could dig one cubic meter of earth per day (cf. Xie et al. 2015's experimental study on the productivity of earthen working), this would have required an estimated 22day's worth of work for 1000 labourers. Therefore, to dig the entire moat, it would have needed a much larger number of workers.

However, such estimations are not without problems. First, these calculations are not based on a reliable chronological evidence and are therefore often simplistic and sometimes misleading. In their groundbreaking research on the Neolithic enclosures (some with circling ditches) of southern Britain and Ireland, Whittle and colleagues have proposed a number of different scenarios concerning the organization of labor input and duration in the construction of these earthworks. Supported by their systematic re-examination of calibrated radiocarbon dates, they suggest that proportionate effort was spent on building works in different periods (Whittle et al., 2011, p. 695). In other words, realizing that the construction of moats and walls was often a gradual and intermittent process, how to gain insights into this complicated process is a difficult question. Evans and Hodder, approaching this question from another angle, offer the 'unit of labor' (Evans and Hodder, 2006), which would try and determine how the earthworks were constructed. Further complicating the issue was the labor cost in maintenance, which would have involved cleaning or desilting, protecting walls from collapsing, and widening or digging new channels. Some of these processes have been observed in our micromorphological examination at Wadian, but a full assessment is not currently possible.

\section{Construction and Use of the Moat within broader environmental and cultural contexts}

As discussed above, the groundwater table during occupation was high and the moat was connected with the natural river when it was first dug. Similarly, moats at other contemporary sites in the same region were also connected to natural river channels, such as that at the Wangchenggang site. Not only would this have played a crucial factor in mitigating flooding risks, it might have also facilitated rice farming, a subsistence strategy that would have been new to the local farmers. Whilst the current local hydrological condition in the Ying River is generally not suitable for rice farming, when the groundwater level was high during the Longshan period in the late Holocene, the shallow moat located on the alluvial plain would have provided sufficient water for rice farming, which would have likely been practiced on the flat lands of the river floodplain. The presence of rice spikelet bases in the aforementioned archaeobotanical assemblage at Wadian confirms the existence of rice farming around the site. Future archaeobotanical research should focus on how rice farming was practiced at Wadian and the physiological responses of rice and weeds of rice to this modified ecosystem.

From a regional perspective, the functions of late Neolithic moats, along with rammed-earth walls, are highly debated amongst Chinese archaeologists. In particular if moats were being used for defensive purposes. The late Neolithic saw a 
dramatic increase of violence across different parts of North China. Archaeological evidence of this appears at both large and small sites, characterised by the frequent presence of wounds afflicted through violent trauma on human skeletons. Again at Wangchenggang, for example, many sacrificial pits underneath house foundations have been excavated in an encircled area. One of them had seven skeletons placed in more than 20 rammed-earth layers (Henan Provincial Institute of Cultural Relics and Archaeology and Department of Archaeology, 1992). This pronounced increase in violence prompts the popular speculation that the construction of extensive late Neolithic moats and walls coincided with the increasing need for defense and that the moats and walls were at the core of this defensive systems. This opinion, however, fails to take into account the archaeological contexts of these finds related to this evidence of violence. There is a need to differentiate violence which occurred in domestic domains from that which took place in regional conflicts to avoid generalizing the functions of walls and moats without considering their wider archaeological contexts.

The late Neolithic in China was also a period of population growth and agricultural intensification, with the introduction and frequent movement of new species in different parts of China. Some of the most notable developments include the introduction of wheat cultivation into China (Flad et al., 2010), the increasing importance of rice farming for local subsistence (Jin et al., 2007, 2016), and the establishment of inter-cropping system (Qin, 2012). Even though these

developments were quite localised, would they have been large enough to stimulate changes in the way economic production was organised? In the past in Southeast and South Asia and other parts of the world, moats, along with many other small features (e.g., small ditches for water diversion), played a vital role in water storage and re-distribution (Fletcher et al., 2008; Higham, 1989, 2001; Scarborough, 2003). Very little is known about the development of irrigation in late Neolithic China, but it is an important aspect that needs to be interrogated in light of new archaeobotanical and geoarchaeological evidence.

\section{Beyond the Practical Functions of Moats}

Beyond their practical functions, moats were places in which different kinds of communal and ritual activities could take place, as demonstrated by the pioneering research undertaken in the UK and other parts of the world (see Jones, 2008; Kinnes, 1979). Piles of objects and whole animal skeletons or disarticulated animal bones are often unearthed from moats. They are often interpreted as deliberate disposals during ritual activities (Richards, 1996; Thomas, 2005). Further archaeological research on these types of deposits could deepen our understanding of how these activities were carried out. For example, radiocarbon dating animal bones would provide important information regarding the timing and frequency of animal offerings; detailed analysis of age profiles on the bones would determine whether there was any preferences in using certain types of animals; and geoarchaeology would be able to reveal information regarding whether fire or related activities were involved. This type of special disposal of animal bones may have also existed in prehistoric China. At the site of Yangguanzhai (Middle Yangshao, c. 6000-5500 BP) in Shaanxi, for example, a recent excavation has recovered abundant animal bones in 
the moat near the western gate of this huge settlement (Hu et al., 2011). The significance of this discovery to the study of prehistoric human behavior merits more research.

A radical view in the debate on the functions of prehistoric moats focuses on the construction processes and suggests that the process itself was the 'prime purpose' of prehistoric communities (cf. Evans and Hodder, 2006). In that the 'act' of the construction was vitally important as it would have been a 'major communal enterprise' that was 'as important for social cohesion as the rituals that may have been performed' there (cf. Andersen, 2002). Similar ideas have been proposed in the study of prehistoric moats and walls in China. According to some scholars, the appearance of walled site clusters in some tributaries of the Middle Yangtze River was an outcome of regional competition which greatly stimulated the construction of walls and moats at regional central sites first and later at second-tier sites (Zhang, 2013). Such new perspectives should be welcomed in future research as they help to contextualize walls and moats in the late Neolithic landscape which was becoming increasingly intertwined with cultural and economic activities.

\section{Conclusions}

Our geoarchaeological survey and micromorphological examination provide, for the first time, environmental evidence for the significant agricultural development during the late Holocene, that is, the spread of rice farming in North China. Our research demonstrates a managed local landscape near Wadian through the construction and management of the moat and the walls as well as other economic activities undertaken by this late Neolithic society. Admittedly, our thin section sample size at Wadian is small and the information obtained concerning the 'life cycle' of the moat reflects just one section of a large moat. However, contextualized within its archaeological and environmental backgrounds, our micromorphological examination and geoarchaeological survey have proved to be a fruitful attempt to disentangle how the moat was constructed, used and abandoned and how these series of activities were constrained by and transformed the local environment. We have shown that the moat was built on top of an alluvial plain and was connected with natural water courses on the plain initially. The depth of the moat was shallow and most of the time filled with water. This may have been related to the emergence of rice farming at the site. Evidence of digging and cleaning of the bottom of the moat was found in our examination. However, whether the moat was maintained regularly and how much labor was invested towards its maintenance remains unclear. The moat was in continuous use later on, but was gradually silting up due to a steadily increasing sedimentation rate. This was caused not only by changes in the regional hydrological and sedimentary regimes but was also closely associated with the increasing anthropogenic activities taken place nearby the moat which continuously supplied sediments to the moat through surface erosion. The later stage of the 'life cycle' of the moat was coincident with a precarious hydrology, frequently alternating between wet and dry conditions, which was linked to regional environmental changes. Our research sheds new light onto the heated debate surrounding the construction and functions of late Neolithic moats in China. We suggest that in the investigation of past land use and its relationship with long-term 
landscape change, there is a need to combine detailed information derived from the reconstruction of sedimentary-pedogenetic sequences with the broader environmental and cultural contexts.
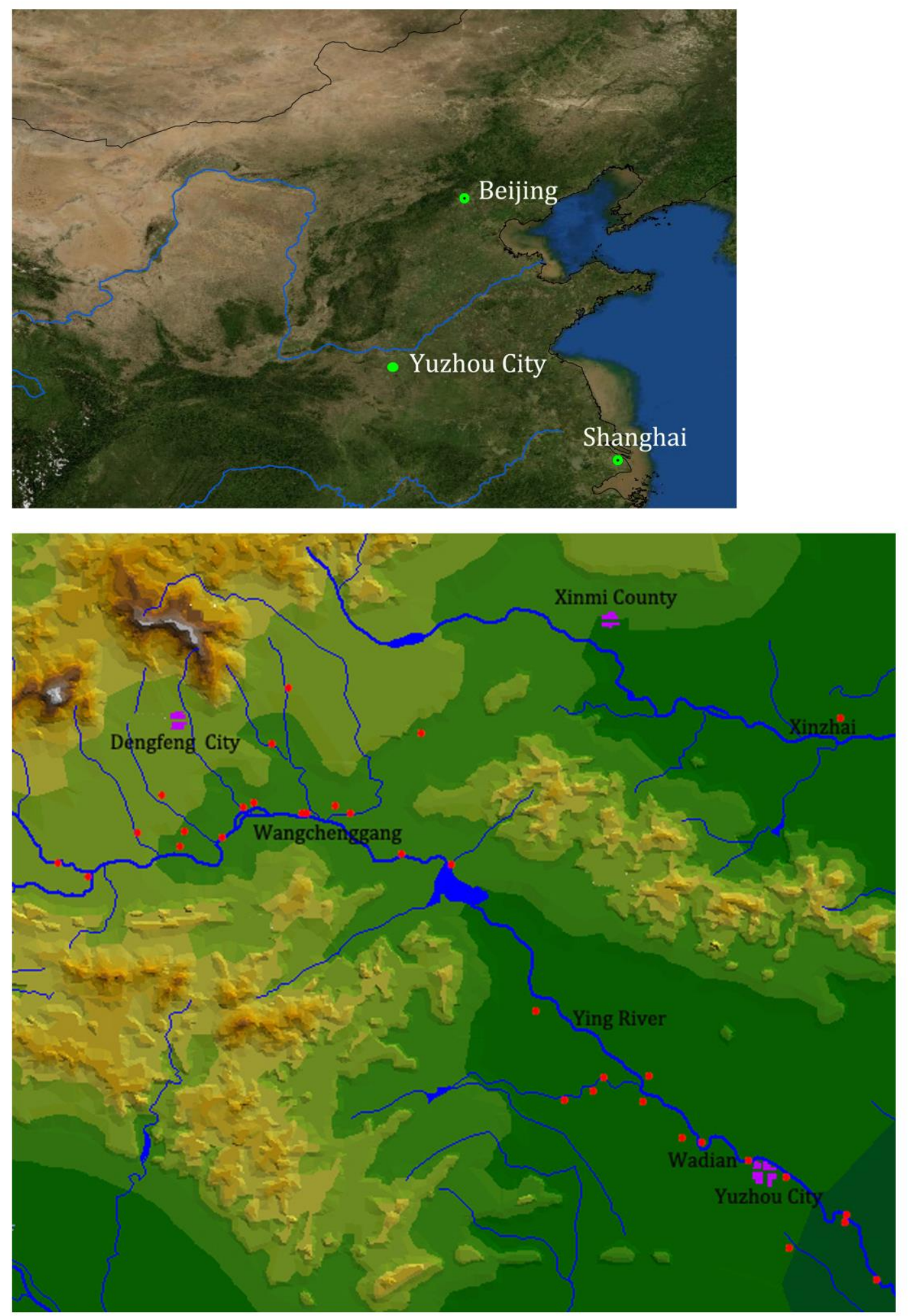

Figure 1: Location of the Ying River and names of the sites mentioned in the text. 

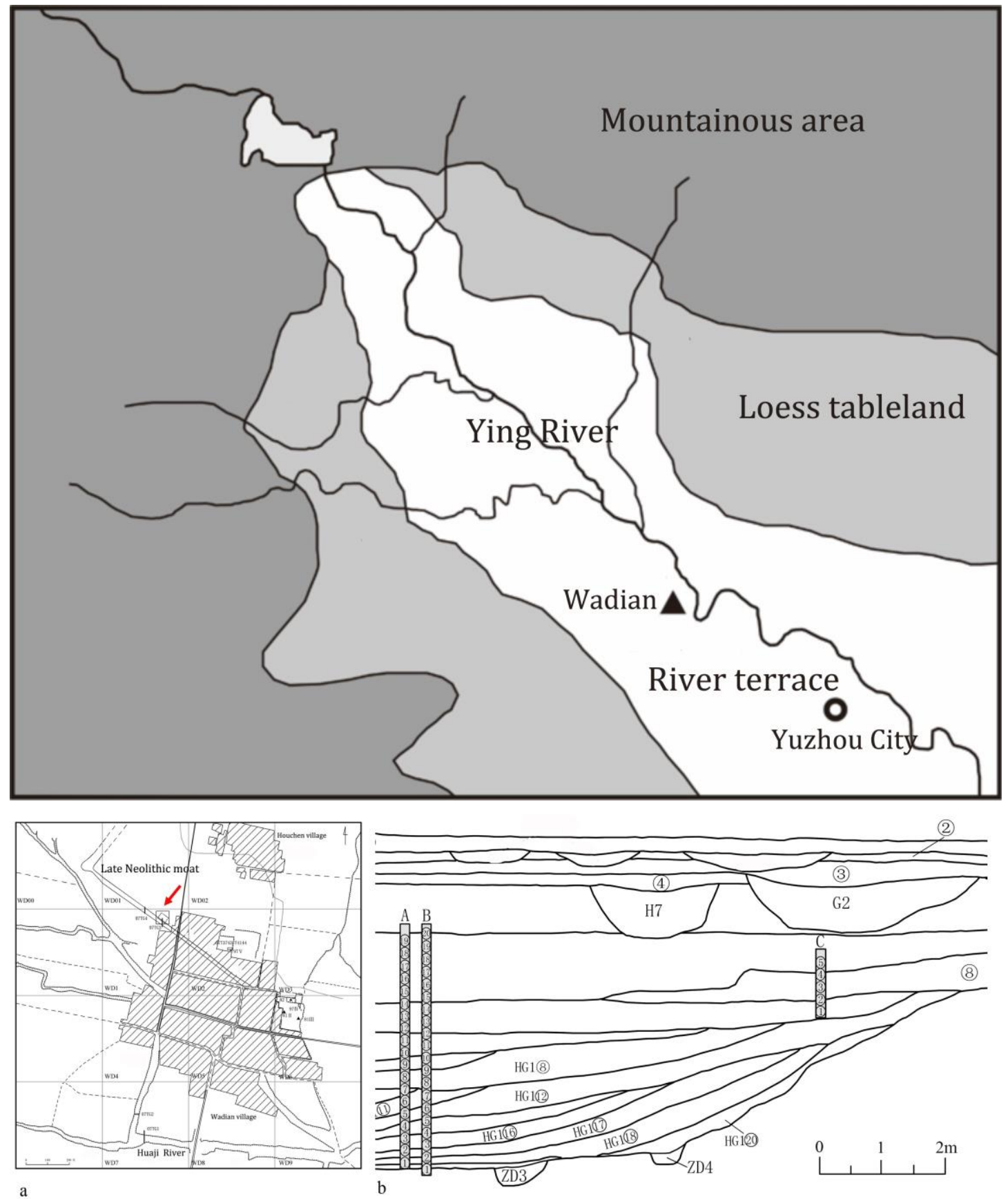

Figure 2: Geomorphological setting around the Wadian site, ranging from the mountainous area, the loess tablelands, and the river terraces and floodplains. Modified after Wang et al., 2015. 

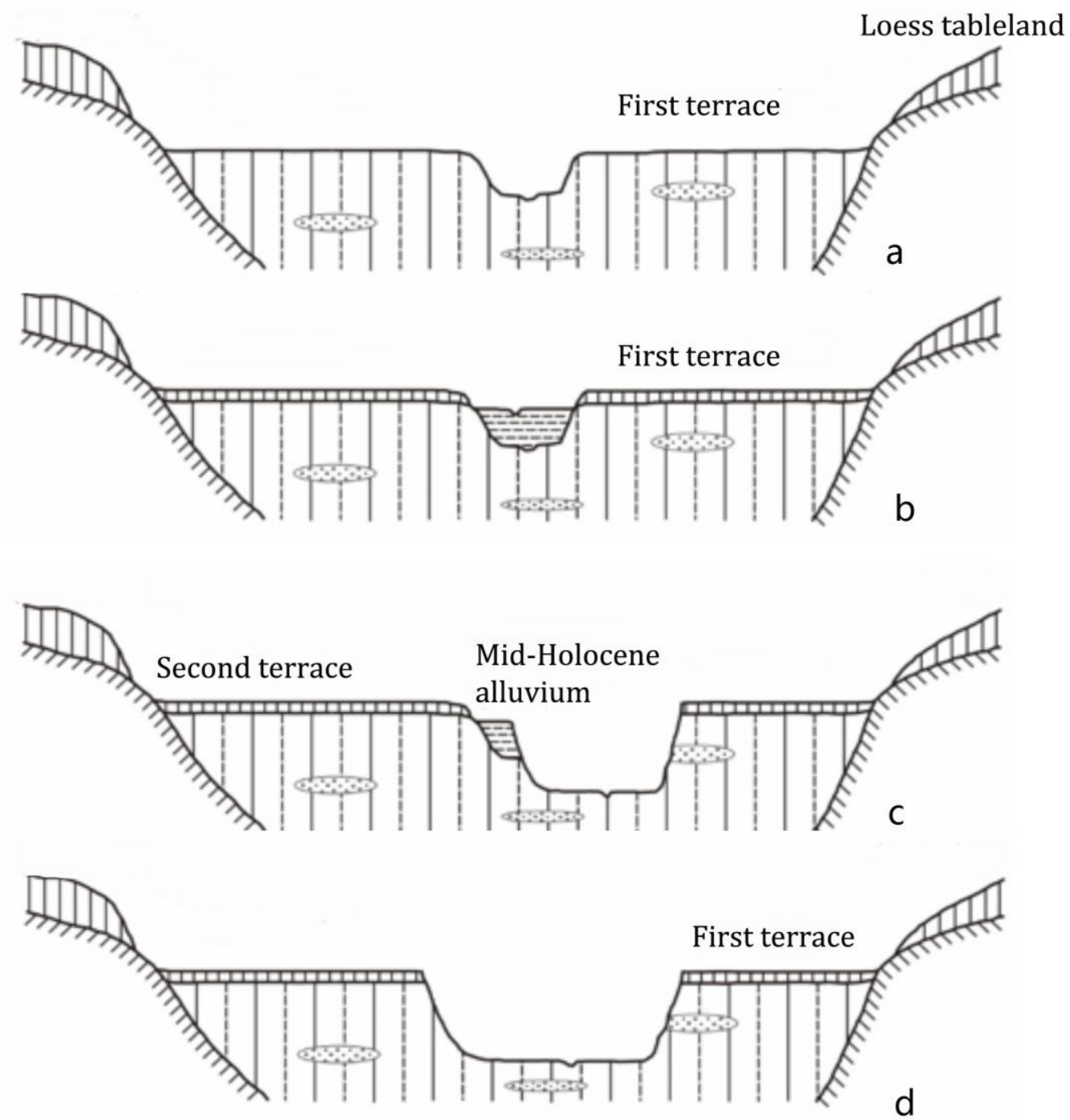

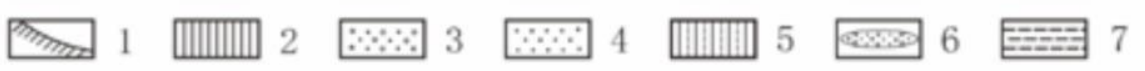

Figure 3: a: location of the late-Neolithic moat at Wadian, red arrowhead points the excavation trench where samples were collected. $b$ : incomplete outline of the section of the moat, showing locations of the sampling sequences $\mathrm{A}, \mathrm{B}$ and $\mathrm{C}$. 


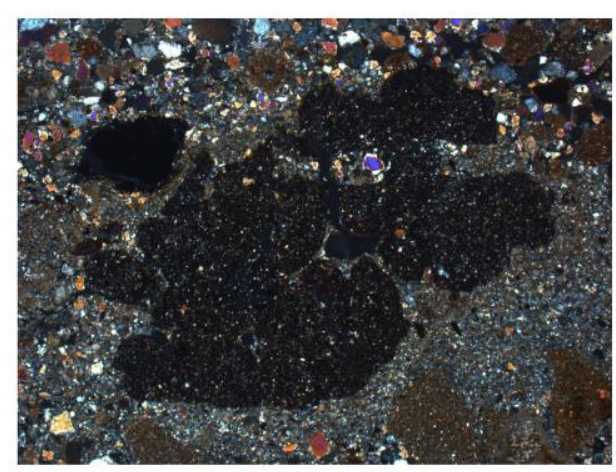

a

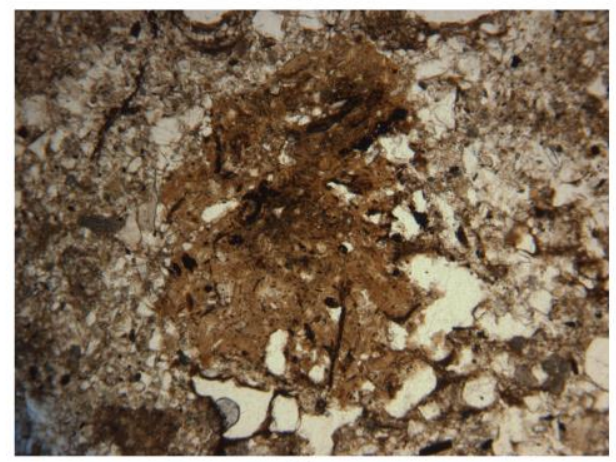

$\mathrm{C}$

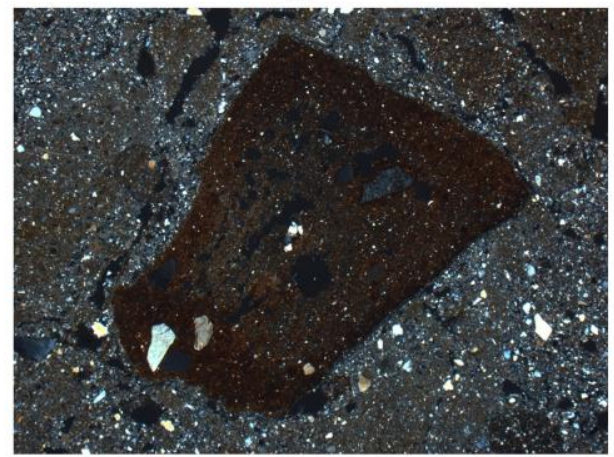

$\mathrm{e}$

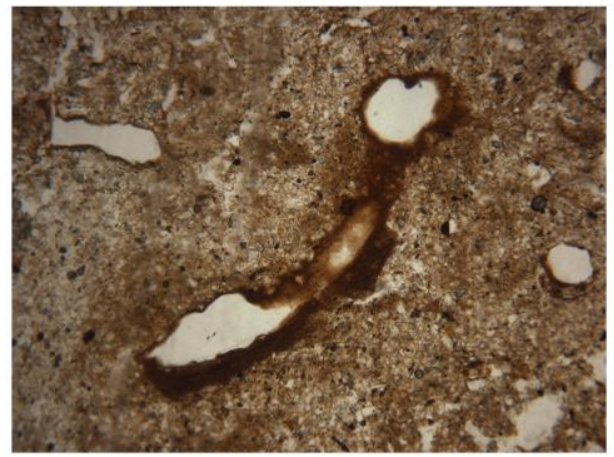

$\mathrm{g}$

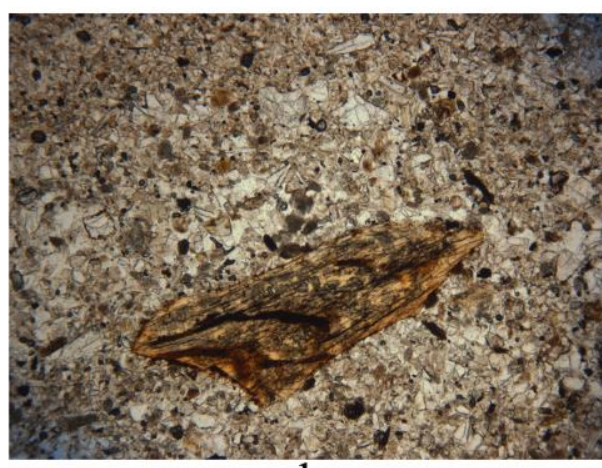

b
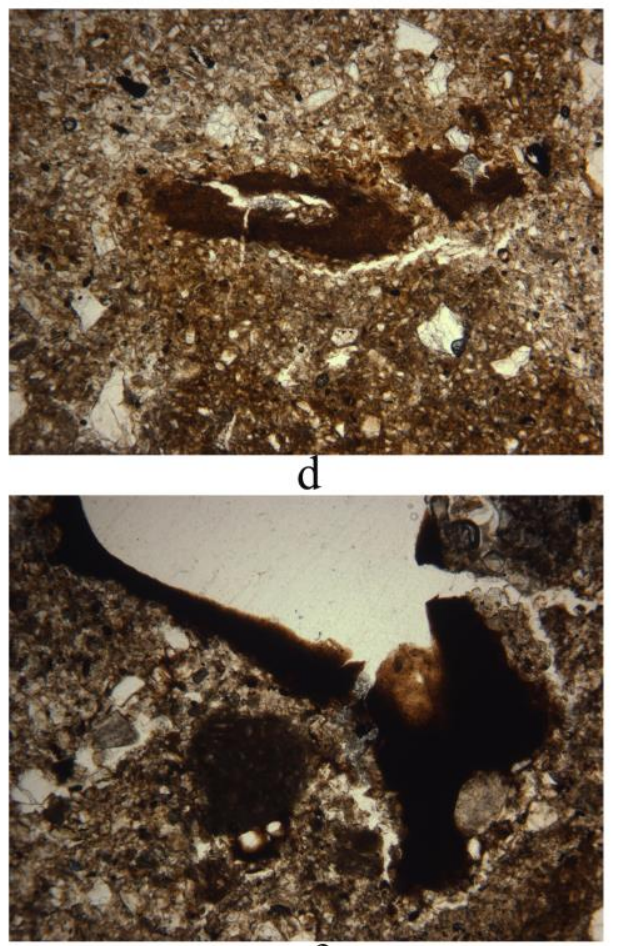

f

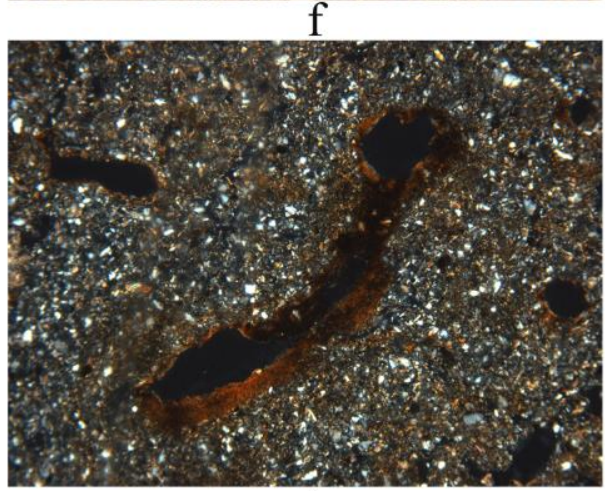

$\mathrm{h}$

Figure 4: Schematic sketches showing Holocene riverine geomorphology. a: the Ying River during the Pleistocene/Holocene transitional period. b: alluvial activities during the mid-Holocene, dominated by the formation of the first terrace and continuous aggradation of the river channel bed. c: river downcutting from the late-Holocene onwards. This led to the formation of the second terrace and the widening of the river channel. d: the Ying River valley during in the later historical period with active downcutting processes. Legends: 
1: geological bedrock; 2: loess deposits; 3: sandy-gravel layers; 4: sandy layers; 5: reworked loess deposits; 6: sandy-gravel lens; 7: alluvial-lake like deposits. After Wang et al., 2015.

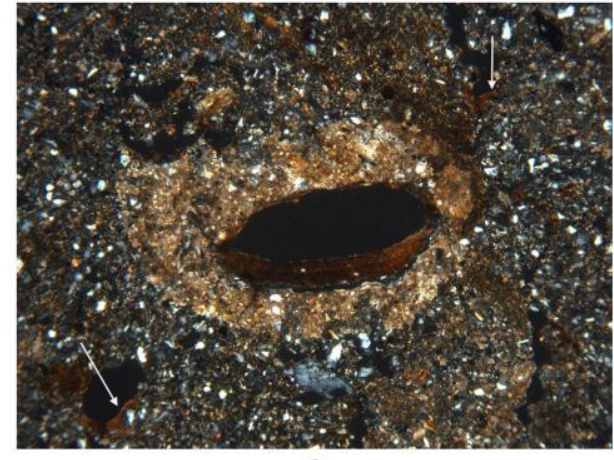

a

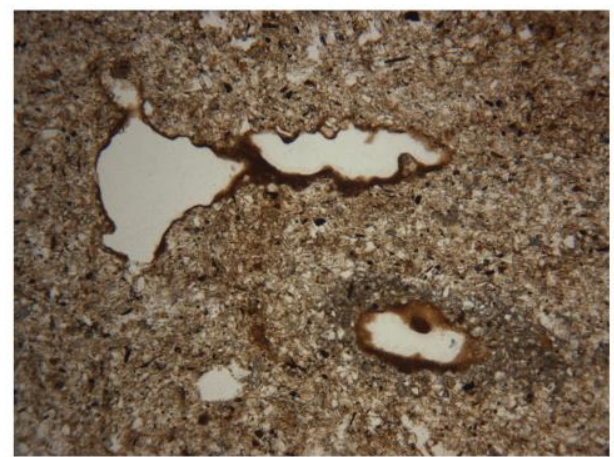

C

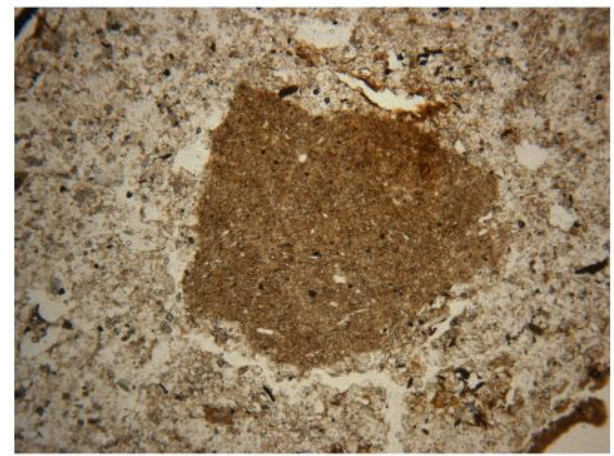

e

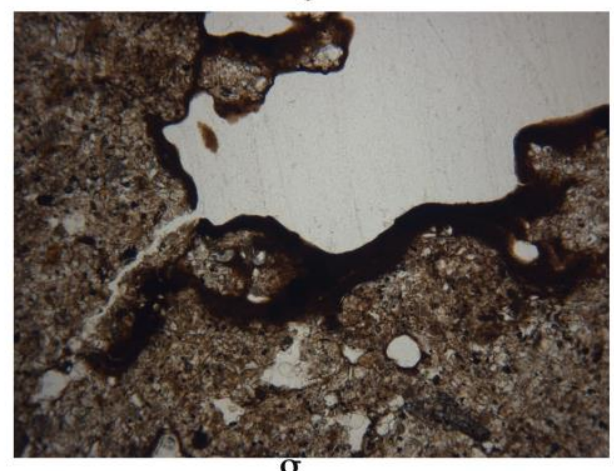

$\mathrm{g}$

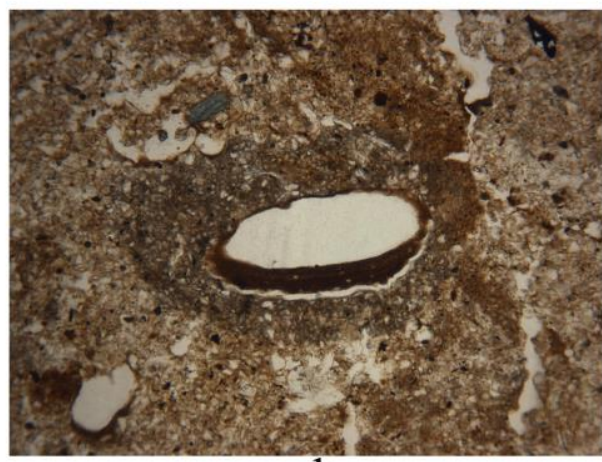

b

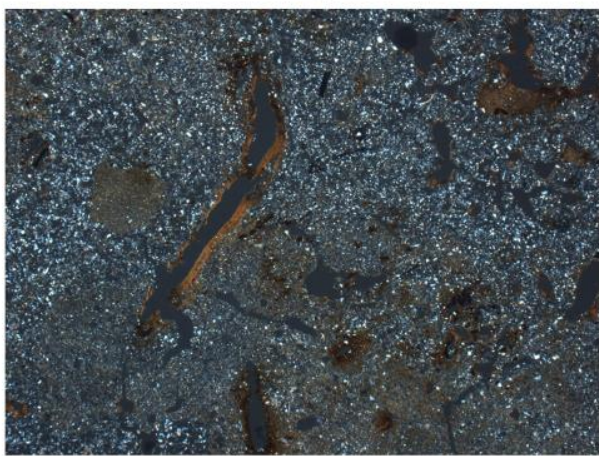

d

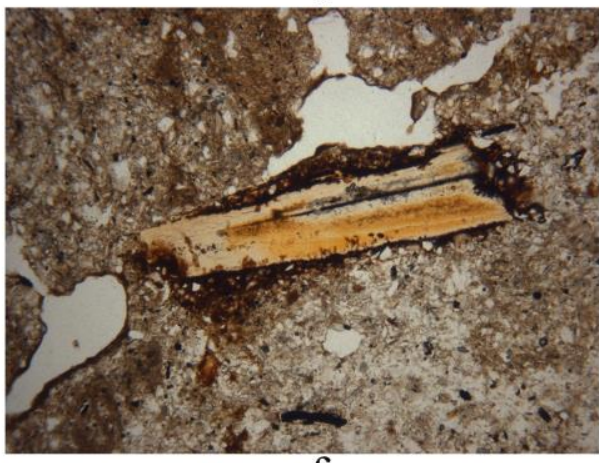

f

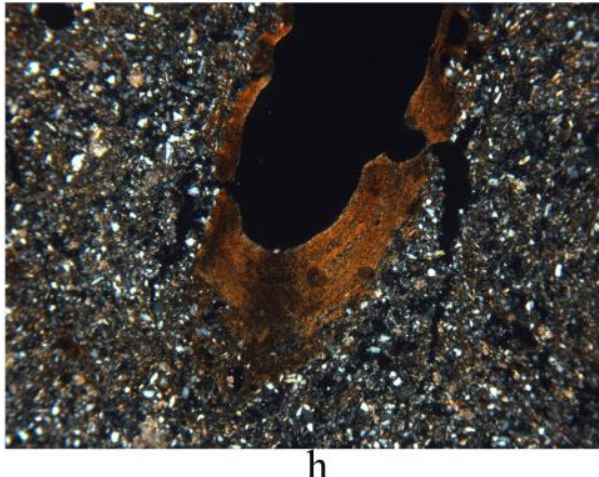

h

Figure 5: a: eroded soil aggregates get re-deposited. Note the poorly to moderately sorted fine sand layer overlying on top of a well sorted silty layer 
with a sharp boundary, XPL (cross polarised light, same below). b: bone fragment with some degree of mineralisation as shown by its yellowish-reddish colour, PPL (plane polarised light, same below). c: dung fragment showing brownish-reddish colour, with some organic matter still being preserved, PPL. d: disrupted clay textural feature well embedded in the poorly sorted groundmass, PPL. e: pottery sherd in the groundmass. Note the dark reddish colour and the minerals in the sherd, XPL. f: dusty clay coatings without birefringence, also note the dusty particles along the edge of the coatings, PPL. g: silty clay coatings and hypo-coatings with moderate birefringence, PPL. h: same in XPL. Image sizes: a and e, $11.2 * 8.4 \mathrm{~mm} ; \mathrm{b}, \mathrm{c}, \mathrm{d}, \mathrm{f}, \mathrm{g}$ and $\mathrm{h}, 2.8^{*} 2 \mathrm{~mm}$. 


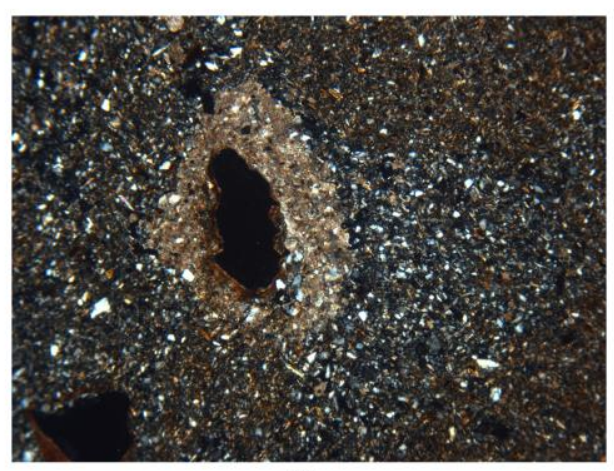

a

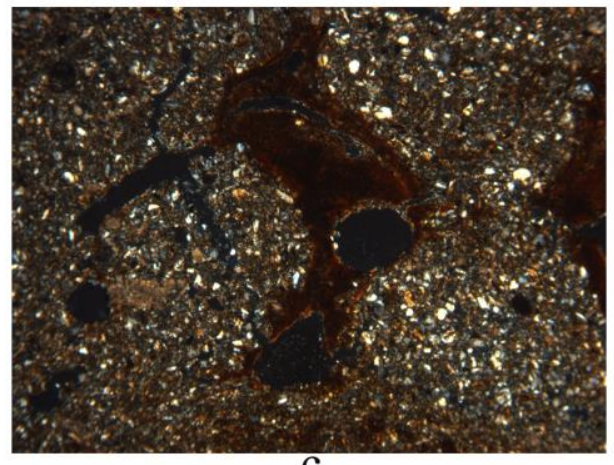

C

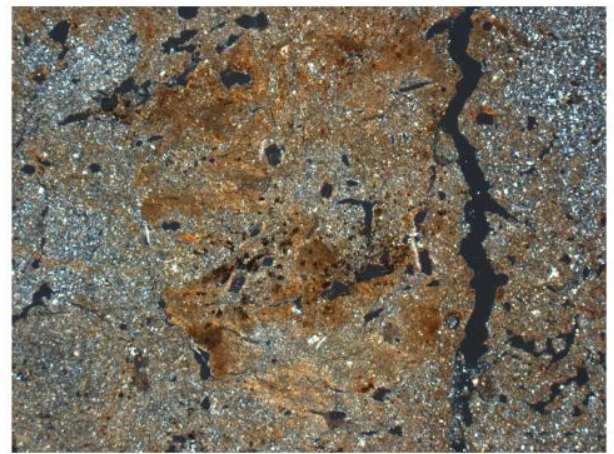

e

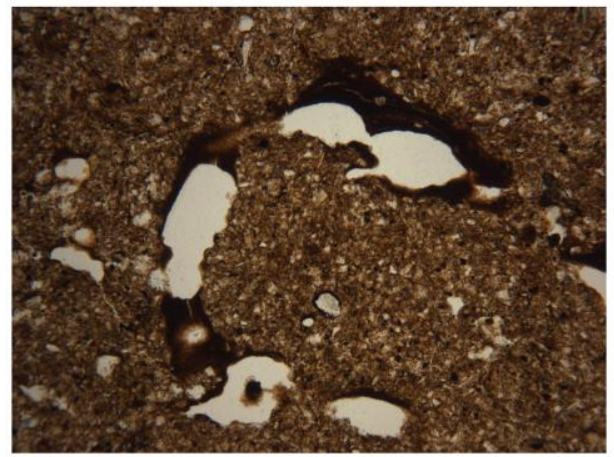

$\mathrm{g}$

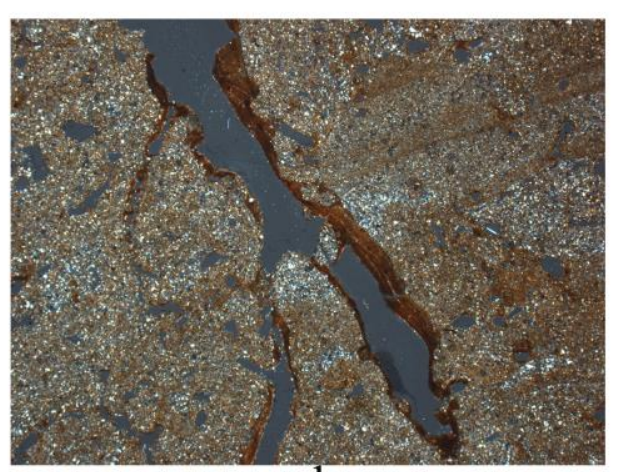

b

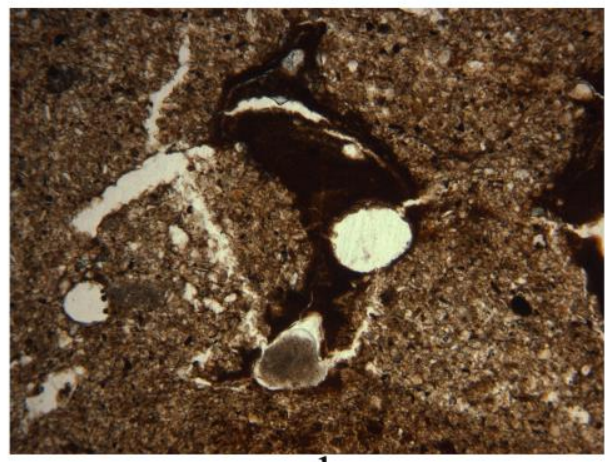

d

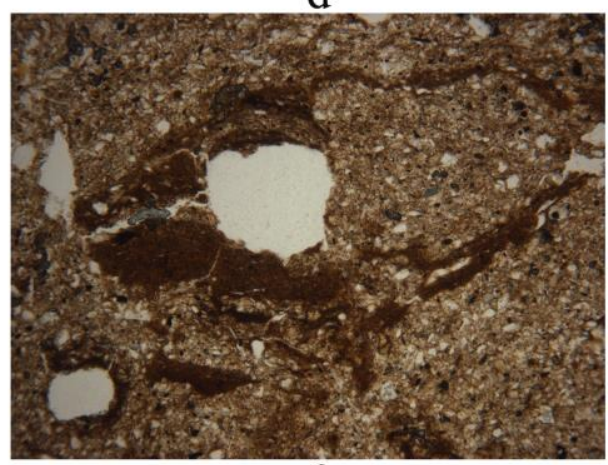

f

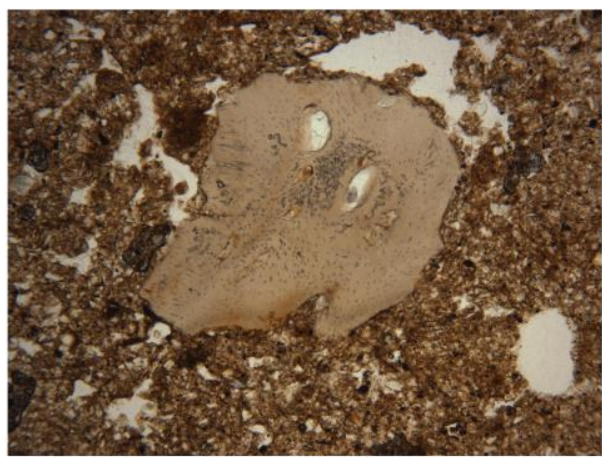

$\mathrm{h}$

Figure 6: a: layered dusty clay coatings juxtaposing with calcitic hypo-coatings, with moderate birefringence, and thin dusty clay coatings (white arrowheads) showing lighter brownish colour, XPL. b: same in PPL, note the colour of the calcitic hypo-coatings. c: thin dusty clay coatings in the well sorted groundmass. Note the dusty particles in the middle, PPL. d: layered dusty clay coatings and hypo-coatings. Note the clay rich and depleted areas in the groundmass, XPL. e: disrupted clay pedofeature embedded in the groundmass, PPL. f: bone fragment 
covered and surrounded by iron minerals, PPL. g: dusty clay coatings. Note some features almost completely filling the voids, PPL. h: layered, limpid to dusty clay coatings with moderate to strong birefringence, XPL. Image sizes: $a, b, c, e, f, g$ and $\mathrm{h}, 2.8 * 2 \mathrm{~mm} ; \mathrm{d}, 11.2 * 8.4 \mathrm{~mm}$.

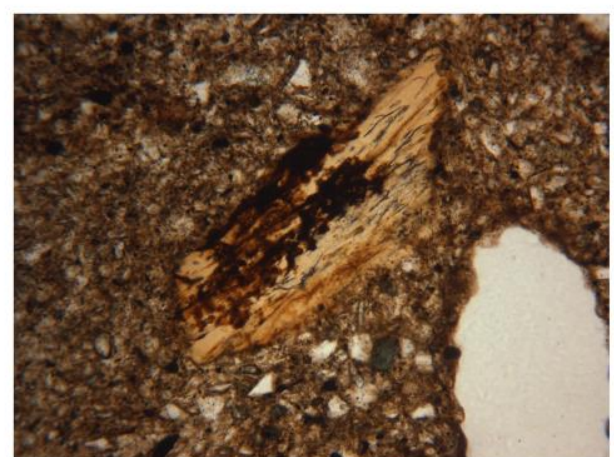

a

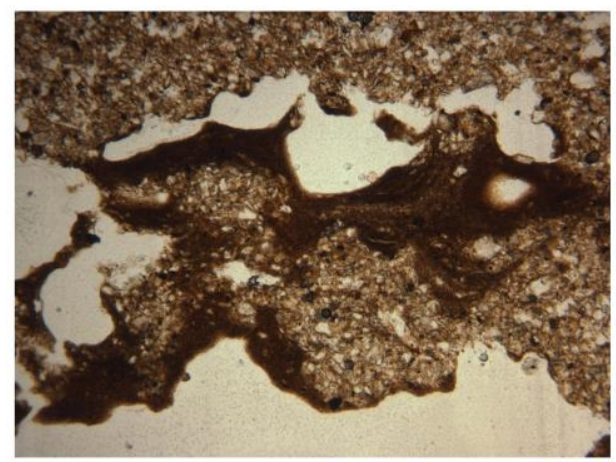

$\mathrm{C}$

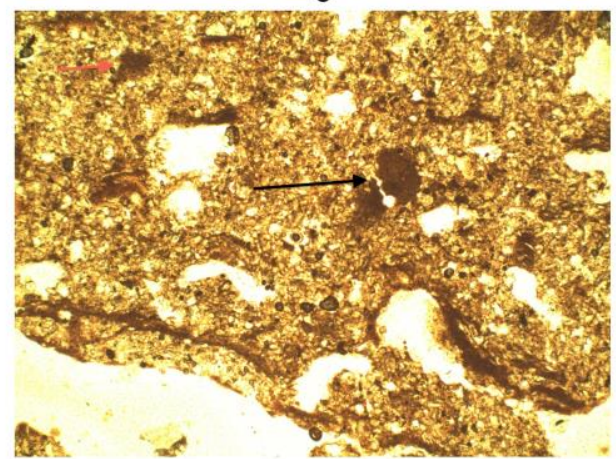

e

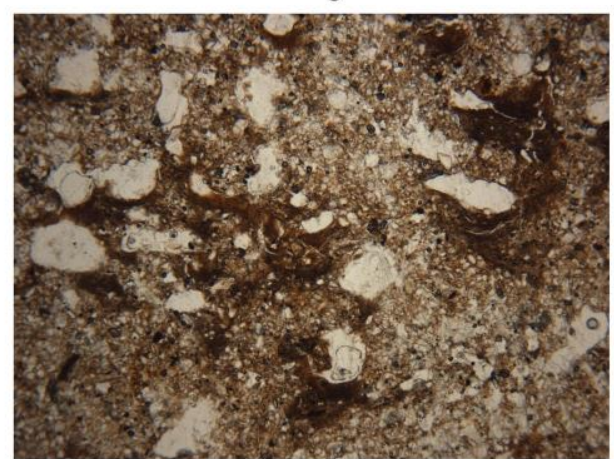

g

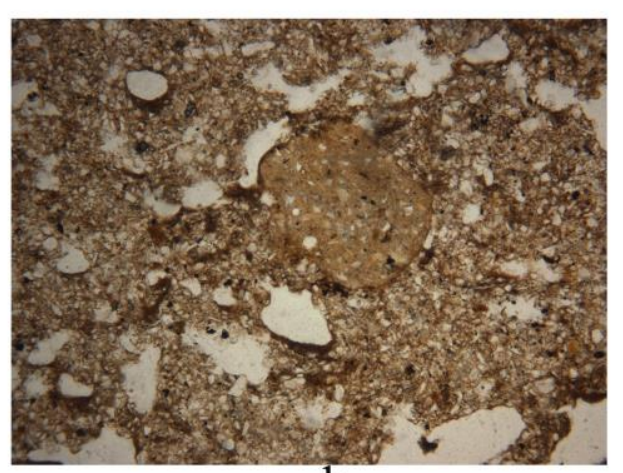

b

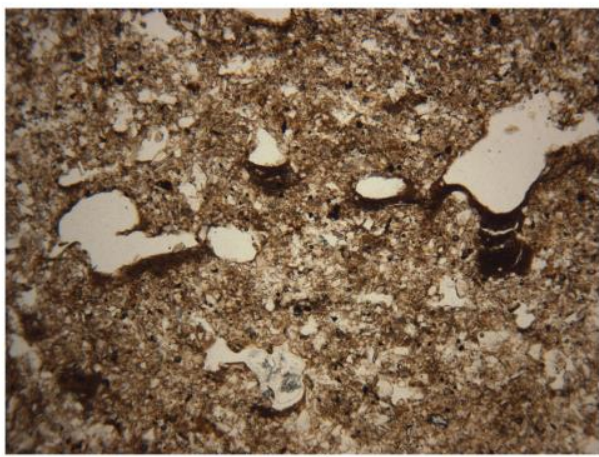

d

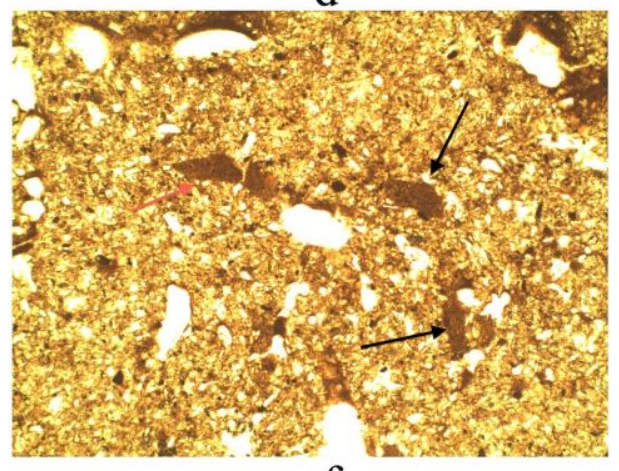

$\mathrm{f}$

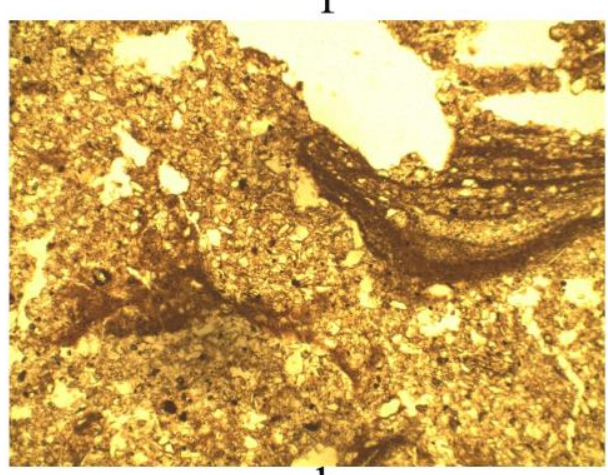

h

Figure 8: a: bone fragment covered by iron rich nodule-like features, PPL. b: rounded-shaped dung fragment, showing a light brownish yellowish colour, also 
note the thin dusty clay coatings located along the lower halves of voids, PPL. c: layered, dusty clay coatings and hypo-coatings. Note the dusty particles along the void in the center, PPL. d: layered dusty clay coatings located along the lower halves of voids, PPL. e and f: silty clay concentration features (black arrowheads), clay hypo-coatings, and partially disrupted clay textural features (red arrowheads), PPL. g: layered dusty clay coatings and hypo-coatings located along the lower halves of voids. Note their light reddish to darkish-brownish colours, PPL. h: surface crustal features, PPL. Image sizes: a, $1.1^{*} 0.84 \mathrm{~mm} ; \mathrm{b}, \mathrm{c}, \mathrm{d}$, e, f, g, and h, 2.8*2mm. 

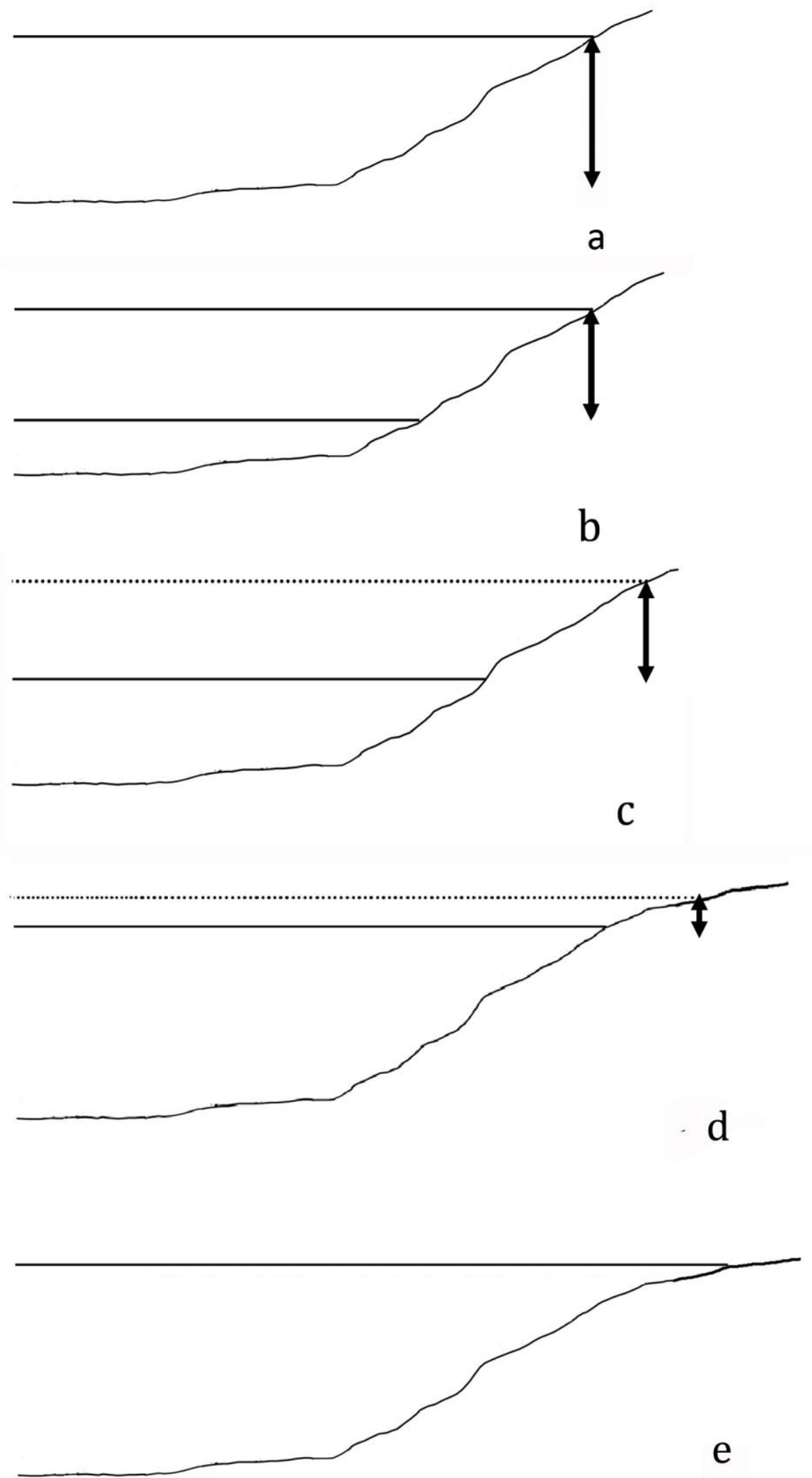
Figure 9: Schematic diagrams reconstructing the pedo-sedimentary processes in the life cycle of the moat at Wadian. a: Representing the initial stage when the moat was first dug and connected to the natural river. The water table was high. Abundant anthropogenic inclusions were found. b: Stage 2 when the bottom of the moat was gradually aggrading without an obvious interruption. Water table remained relatively high, whereas anthropogenic inclusions were reduced. This stage represents a stable landscape surrounding the moat. c: During this stage, the upward aggradation continued; but downward soil formation processes were also taking place. This stage also witnessed more frequent water table fluctuations. d: Stage 4 is predominated by both upward aggradation and downward soil formation. The water became shallower but in the meantime, the moat was widened by the residents. Increased anthropogenic inclusions. e: Stage 5 , the moat almost completely silted up. Soil formation processes became active with more frequent wet-dry alternations in the soil. Double-headed arrows represent water depth; solid lines (lower ones) represent bottom of the moat; dash lines represent fluctuating water levels.

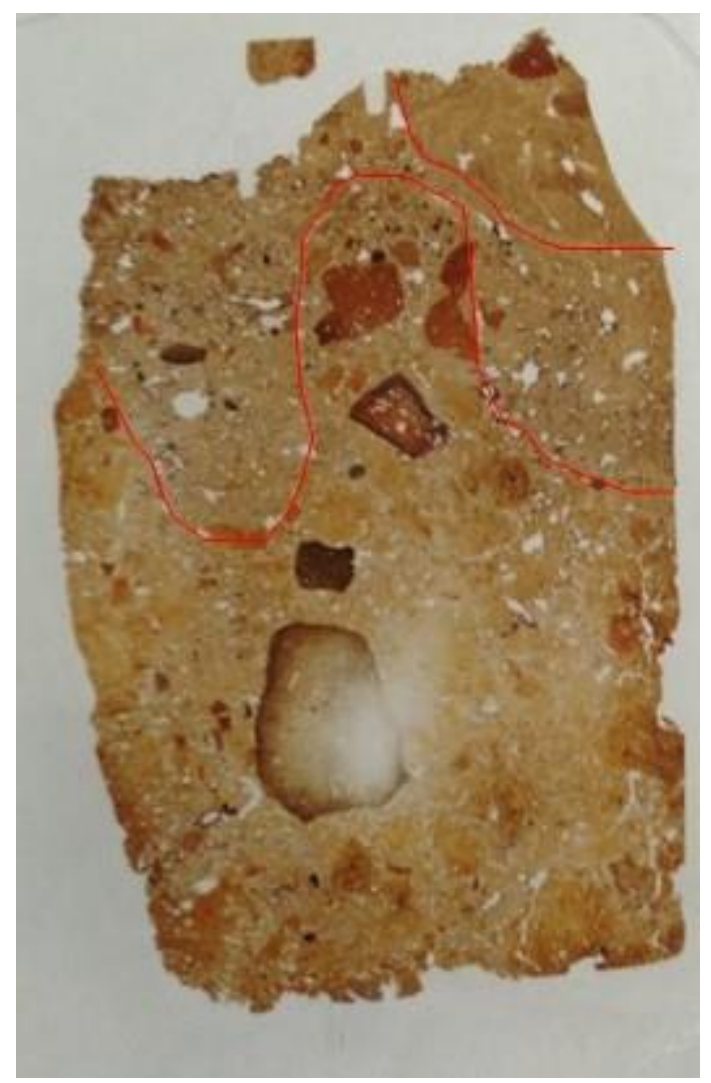

Figure 10: Preserved tool marks characterised by their symmetric grooves, which were filled up by relatively 'clean' sediments. Image size: $10 * 5 \mathrm{~cm}$.

\begin{tabular}{|c|c|c|c|c|c|}
\hline Lab & & & & Calit & C) \\
\hline numbe & Sample & $\begin{array}{l}\text { Original } \\
\text { number }\end{array}$ & $\begin{array}{c}\text { 14C dates } \\
\text { (BP) }\end{array}$ & $1 \sigma(68.2 \%)$ & $2 \sigma(95.4 \%)$ \\
\hline
\end{tabular}




\begin{tabular}{|c|c|c|c|c|c|}
\hline $\begin{array}{c}\text { BA085 } \\
34\end{array}$ & $\begin{array}{c}\text { Charcoa } \\
\text { I }\end{array}$ & $\begin{array}{l}\text { 2007W } \\
\text { D1TG3 } \\
\text { 10. }\end{array}$ & $\begin{array}{c}2565 \pm 39 \\
(45)\end{array}$ & $\begin{array}{c}\text { 810BC (40.6\%) } \\
740 B C \\
690 B C(11.5 \%) \\
660 B C \\
640 B C(16.1 \%) \\
590 B C \\
\end{array}$ & $\begin{array}{c}820 \mathrm{BC}(95.4 \%) \\
530 \mathrm{BC}\end{array}$ \\
\hline $\begin{array}{c}\text { BA085 } \\
37\end{array}$ & $\begin{array}{c}\text { Charcoa } \\
\text { I }\end{array}$ & $\begin{array}{l}\text { 2007W } \\
\text { D1TG3 } \\
(23)\end{array}$ & $\begin{array}{c}3650 \pm 25 \\
(35)\end{array}$ & $\begin{array}{c}2120 \mathrm{BC}(14.3 \%) \\
2090 \mathrm{BC} \\
2040 \mathrm{BC}(53.9 \%) \\
1950 \mathrm{BC} \\
\end{array}$ & $\begin{array}{c}2140 \mathrm{BC}(95.4 \%) 19 \\
20 \mathrm{BC}\end{array}$ \\
\hline $\begin{array}{c}\text { BA085 } \\
42\end{array}$ & Bone & $\begin{array}{l}\text { 2007W } \\
\text { D1TG4 } \\
(18)\end{array}$ & $\begin{array}{l}3575 \pm 49 \\
\quad(55)\end{array}$ & $\begin{array}{c}2030 \mathrm{BC}(63.6 \%) \\
1870 \mathrm{BC} \\
1840 \mathrm{BC}(3.2 \%) \\
1820 \mathrm{BC} \\
1800 \mathrm{BC}(1.4 \%) \\
1780 \mathrm{BC} \\
\end{array}$ & $\begin{array}{c}2120 \mathrm{BC}(2.6 \%) 209 \\
\text { OBC } \\
2040 \mathrm{BC}(92.8 \%) 17 \\
50 \mathrm{BC}\end{array}$ \\
\hline $\begin{array}{c}\text { BA085 } \\
43\end{array}$ & Bone & $\begin{array}{l}\text { 2007W } \\
\text { D1TG4 } \\
(19)\end{array}$ & $\begin{array}{c}3385 \pm 36 \\
(45)\end{array}$ & $\begin{array}{c}1740 \mathrm{BC}(68.2 \%) \\
1620 \mathrm{BC}\end{array}$ & $\begin{array}{c}1870 \mathrm{BC}(2.3 \%) 184 \\
\text { OBC } \\
1780 \mathrm{BC}(93.1 \%) 15 \\
\text { 30BC }\end{array}$ \\
\hline
\end{tabular}

Table 1: Radiocarbon dates of charcoal and bone samples collected from the moat. Also see Figure 3 for the context.

Acknowledgement: Soil thin sections were produced in the McBurney Laboratory, Division of Archaeology, University of Cambridge, with assistance from Charles French and Tonko Rajkovaca.

Andersen, N.H., 2002. Neolithic enclosures of Scandinavia, 515 in: Varndell, G., Topping, P. (Eds.), Enclosures in Neolithic Europe: Essays on Causewayed and Non-Causewayed Sites. Oxbow, Oxford, pp. 1-10.

Bridge, J.S., 2003. Rivers and Floodplains: Forms, Processes, and Sedimentary Record. Blackwell Pub, Oxford.

Bullock, P., Fedoroff, N., Jongerius, A., Stoops, G., Tursina, T., 1985. Handbook for Soil Thin Section Description. Waine Research Publications, Wolverhampton.

Evans, C., Hodder, I., 2006. A Woodland Archaeology: The Haddenham Project Volume I. Oxbow, Oxford.

Fedoroff, N., Courty, M.A., Guo, Z.T., 2010. Palaeosoils and relict soils, in: Stoops, G., Marcelino, V., Mees, F. (Eds.), Interpretation of Micromorphological Features of Soils and Regoliths. Elsevier, Amsterdam, pp. 623-662.

Flad, R., Li, S.C., Wu, X.H., Zhao, Z.J., 2010. Early wheat in China: Results from new studies at Donghuishan in the Hexi Corridor. The Holocene 20, 955-965. 
Fletcher, R., Penny, D., Evans, D., Pottier, C., Barbetti, M., Kummu, M., Lustig, T., APSARA (Authority for the Protection and Management of Angkor and the Region of Siem Reap) Department of Monuments and Archaeology Team, 2008. The water management network of Angkor, Cambodia. Antiquity 82, 658-670.

Fuller, D.Q., Zhang, H., 2007. A preliminary report of the survey archaeobotany of the upper Ying Valley (Henan Province), in: School of Archaeology and Museology, Peking University and Henan Provincial Institute of Cultural Relics and Archaeology (Eds.), Archaeological Discovery and Research at the Wangchenggang Site in Dengfeng (2002-2005). Great Elephant Press, Zhengzhou, 916-958.

Gerrard, J., 1992. Soil Geomorphology: An Integration of Pedology and Geomorphology. Chapman \& Hall, London.

Henan Provincial Institute of Cultural Relics and Archaeology, 2004. Yuzhou Wadian (in Chinese with English abstract). World Publishing Corporation, Beijing.

Henan Provincial Institute of Cultural Relics and Archaeology, Department of Archaeology, National History Museum of China, 1992. Wangchenggang and Yang City, Dengfeng (in Chinese with English abstract). Cultural Relics Press, Beijing.

Henan Provincial Institute of Cultural Relics and Archaeology and Xinmi Historical Association of Yan-Huang, 2002. Excavation of the Longshan walled site at Guchengzhai, Xinmi City, Henan (in Chinese with English abstract). Huaxia Kaogu, 53-82.

Higham, C., 1989. The Archaeology of Mainland Southeast Asia: From 10,000 BC to the Fall of Angkor. Cambridge University Press, Cambridge.

Higham, C., 2001. The Civilization of Angkor. Weidenfeld and Nicolson, London.

Hu, S.M., Wang, W.L., Guo, X.N., Zhang, W., Yang, M.M., 2011. Examination of the faunal remains from the moat near the western gate at the Yangguanzhai site, Gaoling County, Shaanxi (in Chinese with English abstract), Kaogu yu Wenwu, 97-107.

Institute of Archaeology, Chinese Academy of Science, 1963. Xi'an Banpo (in Chinese with English abstract). Cultural Relics Press, Beijing.

Jin, G.Y., Wagner, M., Tarasov, P.E., Wang, F., Liu, Y.C., 2016. Archaeobotanical records of Middle and Late Neolithic agriculture from Shandong Province, East China, and a major change in regional subsistence during the Dawenkou Culture. The Holocene 26, 1-11.

Jin, G.Y., Yan, S.D., Udatsu, T., Lan, Y.F., Wang, C.Y., Tong, P.H., 2007. Phytolith evidence of the Neolithic paddy at the Zhaojiazhuang site (in Chinese with English abstract). Chinese Science Bulletin 52, 2161-2168.

Jones, P., 2008. A Neolithic Ring Ditch and Later Prehistoric Features at Staines Road Farm, Shepperton. Oxbow, Oxford. 
Kemp, R.A., Derbyshire, E., Meng, X.M., 2001. A high-resolution micromorphological record of changing landscapes and climates on the western Loess Plateau of China during oxygen isotope stage 5, Palaeogeography, Palaeoclimatology, Palaeoecology 170, 157-169.

Kinnes, I., 1979. Round Barrows and Ring-ditches in the British Neolithic. British Museum, London.

Kovda, I., Mermut, A.R., 2010. Vertic features, in: Stoops, G., Marcelino, V., Mees, F. (Eds.), Interpretation of Micromorphological Features of Soils and Regoliths. Elsevier, Amsterdam, pp. 109-127.

Kuhn, P., Aguilar, J., Miedema, R., 2010. Textural pedofeatures and related horizons, in: Stoops, G., Marcelino, V., Mees, F. (Eds.), Interpretation of Micromorphological Features of Soils and Regoliths. Elsevier, Amsterdam, pp. 217-250.

Lee, H., French, C., Macphail, R.I., 2014. Microscopic examination of ancient and modern irrigated paddy soils in South Korea, with special reference to the formation of silty clay concentration features, Geoarchaeology 29, 326-348.

Li, S.L., Huang, C.C., Pang, J.L., Wei, G.B., 2008. Material source of the Holocene aeolian loess/paleosol in the upper reach of the Ying River (in Chinese with English abstract), Scientia Geologica Sinica 28, 559-564.

Lindbo, D., Stolt, M.H., Vepraskas, M.J., 2010. Redoximorphic features, in: Stoops, G., Marcelino, V., Mees, F. (Eds.), Interpretation of Micromorphological Features of Soils and Regoliths. Elsevier, Amsterdam, pp. 129-147.

Liu, C., Fang, Y.M., 2010. Archaeobotanical remains from the Wadian site, Henan (in Chinese), Nanfang Wenwu, 55-65.

Liu, L., Chen, X.C., 2012. The Archaeology of China: From the Late Paleolithic to the Early Bronze Age. Cambridge University Press, Cambridge.

Lu, P., 2009. Examination of the faunal remains from the Wadian (in Chinese), in: School of Archaeology and Museology, Peking University, Henan Provincial Institute of Archaeology and Cultural Relics (Eds.), Archaeological discoveries and research at Wangchenggang, Dengfeng (in Chinese with English abstract). Elephant Press, Zhengzhou, pp. 815-915.

McCarthy, P.J., Martini, I.P., Leckie, D.A., 1998. Use of micromorphology for palaeoenvironmental interpretation of complex alluvial palaeosols: An example from the Mill Creek Formation (Albian), southwestern Alberta, Canada, Palaeogeography, Palaeoclimatology, Palaeoecology 143, 87-110.

McCarthy, P.J., Plint, A.G., 1998. Recognition of interfluve sequence boundaries: Integrating paleopedology and sequence stratigraphy, Geology 26, 387-390.

McCarthy, P.J., Plint, A.G., 1999. Floodplain palaeosols of the Cenomanian Dunvegan formation, Alberta and British Columbia, Canada: mMicromorphology, pedogenic processes and palaeoenvironmental implications, in: Marriott, S.B., Alexander, J.

(Eds.), Floodplains: Interdisciplinary Approaches. The Geological Society of London, London, pp. 289-310. 
Murphy, C.P., 1986. Thin Section Preparation of Soils and Sediments. A B Academic Publ., Berkhamsted.

Pagliai, M., Stoops, G., 2010. Physical and biological surface crusts and seals, in: Stoops, G., Marcelino, V., Mees, F. (Eds.), Interpretation of Micromorphological Features of Soils and Regoliths. Elsevier, Amsterdam, pp. 419-440.

Pang, B., Zhang, H., Fang, Y.M., 2013. Preliminary research on the stone spades at the Wadian site, Yuzhou, Henan: New lights on the Xia-Shang period stone spade industry in the Song Mountain region (in Chinese with English abstract), Huaxia Kaogu, 45-52.

Pei, A.P., 2004. Prehistoric moats in China, Dongnan Wenhua, 21-30.

Richards, C., 1996. Monuments as landscape: Creating the centre of the world in late Neolithic Orkney, World Archaeology 28, 190-208.

Scarborough, V.L., 2003. The Flow of Power: Ancient Water Systems and Landscapes. SAR Press, Santa Fe.

School of Archaeology and Museology, Peking University, Henan Provincial Institute of Archaeology and Cultural Relics, 2007. Archaeological discoveries and research at Wangchenggang, Dengfeng (in Chinese with English abstract). Elephant Press, Zhengzhou.

Shelach, G., Teng, M.Y., 2013. Earlier Neolithic 654 economic and social systems of the Liao River Region, Northeast China, in: Underhill, A.P. (Ed.), A Companion to Chinese Archaeology. Wiley-Blackwell, New Jersey, pp. 37-54.

Song, J.X., 2011. The Agricultural Economy during the Longshan Period: An Archaeobotanical Perspective from Shandong and Shanxi. PhD dissertation. UCL Institute of Archaeology, London.

Stoops, G., 2003. Guidelines for Analysis and Description of Soil and Regolith Thin Sections. Soil Science Society of America, Wisconsin.

Thomas, J., 2005. Understanding the Neolithic. Routledge, London.

Vepraskas, M.J., 2001. Morphological features of seasonally reduced soils, in: Richards, J.L., Vepraskas, M.J. (Eds.), Wetland Soils: Genesis, Hydrology, Landscapes, and Classification. Lewis Publishers, Boca Raton, pp. 85-106.

Wang, H., Zhang, H., Zhang, J.F., Fang, Y.M., 2015. Evolution of the alluvial geomorphology and related issues at the Wadian site, Yuzhou, Henan (in Chinese with English abstract). Nanfang Wenwu, 81-87 and 91.

Wang, S.Z., Fang, Y.M., Zhao, Z.J., 2012. Vegetation, paleoclimate and vegetation use during Longshan era: Case studies of anthracology of Wadian site in Henan province (in Chinese with English abstract), Quaternary Sciences 32, 226-235.

Whittle, A., Healy, F., Bayliss, A., 2011. Gathering Time: Dating the Early Neolithic Enclosures of Southern Britain and Ireland. Oxbow, Oxford. 
Xie, L.Y., Kuhn, S., Sun, G.P., Olsen, J.W., Zheng, Y.F., Ding, P., Zhao, Y., 2015. Lablor costs for prehistoric earthwork construction: Experimental and archaeological insights from the Lower Yangzi Basin, China, American Antiquity 80, 67-88.

Xu, J.J., Mo, D.W., Wang, H., Zhou, K.S., 2013. Preliminary research of environmental archaeology in Zhenshui River, Xinmi City, Henan (in Chinese with English abstract), Quaternary Sciences 33, 954-964.

Zhang, C., 2013. The Qujialing-Shijiahe culture in the Middle Yangzi River valley, in: Underhill, A.P. (Ed.), A Companion to Chinese Archaeology. Wiley-Blackwell, New Jersey, pp. 510-534.

Zhao, C.Q., 2013. The Longshan culture in central Henan province, c.2600-1900 BC, in: Underhill, A.P. (Ed.), A Companion to Chinese Archaeology. Wiley-Blackwell, New Jersey, pp. 236-254.

Zhao, C.Y., Lu, P., Yuan, J., Fang, Y.M., 2012. Chemical element and Sr isotope analyses of animal bones from the Wadian site, Yuzhou City, Henan (in Chinese with English abstract), Kaogu, 89-96.

Zhao, H., Wei, J., 2002. Discoveries and research of prehistoric walled sites in China (in Chinese with English abstract), in: Research Centre for Chinese Archaeology, Peking University (Ed.), Ancient Civilization. Cultural Relics Press, Beijing, pp. 1-34.

Zhao, Z.J., Fang, Y.M., 2007. Archaeobotanical remains from the Wangchenggang site, Dengfeng, Henan (in Chinese with English abstract), Huaxia Archaeology, 78-90. 